
\title{
$\begin{array}{ll}\text { Research Square } & \begin{array}{l}\text { Preprints are preliminary reports that have not undergone peer review. } \\ \text { They should not be considered conclusive, used to inform clinical practice, } \\ \text { or referenced by the media as validated information. }\end{array}\end{array}$ \\ Early Growth Stage Root-Associated Endophytes Isolated From Ulex Europaeus L. (Fabaceae) Colonizing Rural Areas in South-Central Chile
}

\section{Hector Herrera}

University of La Frontera

\section{Alejandra Fuentes}

University of La Frontera

Javier Ortiz

University of La Frontera

Javiera Soto

University of La Frontera

\section{Rafael Vorges Da-Silva Valadares}

Instituto Tecnologico Vale, Rua Boaventura da Silva 955

\section{Christian Salas}

Centro de Modelación y Monitoreo de Ecosistemas, Facultad de Ciencias, Universidad Mayor

Cesar Arriagada ( $\nabla$ cesar.arriagada@ufrontera.cl)

University of La Frontera https://orcid.org/0000-0002-8549-6302

\section{Research Article}

Keywords: Bacteria, Endophytes, Fungi, Invasive species, Plant growth-promotion, Symbiosis.

Posted Date: August 23rd, 2021

DOI: https://doi.org/10.21203/rs.3.rs-790842/v1

License: (c) (i) This work is licensed under a Creative Commons Attribution 4.0 International License. Read Full License 


\section{Abstract}

\section{Background and aims}

Ulex europaeus L. (Fabaceae), commonly known as gorse, is an invasive woody shrub that easily grows in several locations across the world. However, little is known about the interactions of this invasive species with soil microorganisms and how these microbes can promote reaching rapid grow-rates at early stages of development. We aim at characterizing the endophytic fungal and bacterial microbiota associated with roots of early growth stage $U$. europaeus colonizing native ecosystems in south-central Chile.

\section{Methods}

Root-associated microorganisms were isolated and identified using standard molecular techniques. Furthermore, plant growth-promoting traits were studied and biocontrol activity was assessed to characterize the early growth stage root-associated taxa.

\section{Results}

Four endophytic fungi belonging to Sordariomycetes and twelve bacteria assigned to Proteobacteria and Actinobacteria were identified as the principal early growth stage root-endophytic taxa. Plant growthpromoting traits were detected in several isolates such as Fusarium acuminatum and Rhodococcus sp. Besides, some of the isolates such as Rhodococcus sp. and Purpureocillium lilacinum showed biocontrol potential against phytopathogenic fungi.

\section{Conclusions}

Our results demonstrate that early growth stage root endophytic taxa associated with $U$. europaeus have beneficial plant growth-promoting traits that can contribute with the rapid growth-rates of the shrub. The interaction with a set of beneficial microorganisms is an additional mechanism to explain the ability of $U$. europaeus for colonizing in various ecosystems.

\section{Introduction}

Ulex europaeus (Fabaceae) is a shrub species having remarkable ecological features and having several impacts in human-dominated landscapes. The species reaches about 3 meters in height, is spiny, has yellow flowers, and densely cover extended areas (Gränzig et al. 2021; Quiroz et al. 2009). Besides, $U$. europaeus can fix Nitrogen, grow fast, reproduce by seeds that can persist for several years, and live from sea level up to $4000 \mathrm{~m}$ in elevation and at several latitudes (Christina et al., 2020). Nonetheless, $U$. europaeus is classified as an invasive species in several regions of the world (Bowman et al., 2008). Once U. europaeus can establish in a location, it can alter the native species diversity, causing loss of threatened species and altering economic activities (Christina et al., 2020; Hornoy et al., 2013). 
Norambuena et al. (2001) pointed out that $U$. europaeus was introduced in Chile for using it as a hedge plant in agricultural lands to keep out livestock and as a fodder source.

The capacity of $U$. europaeus to handle stressing conditions, successful germination and rapid biomass production is often linked to the ability of the plants from the Fabaceae family to establish symbiotic associations with arbuscular mycorrhizal fungi and symbiosis with nitrogen ( $\mathrm{N}$ )-fixing bacteria (Rahayu and Pratiwi, 2020; Toma et al., 2017; Wilgan, 2017). These symbiotic interactions have been reported as key to achieving plant establishment in several stressed environments (Hao et al., 2019; Rahayu and Pratiwi, 2020; Sharma et al., 2020). Successful establishment is also linked to the ability of seeds to survive for long periods in the soil seedbank, with an estimated longevity of 20 years and exceeding 10,000 seeds per $\mathrm{m}^{2}$ (Broadfield and McHenry, 2019). One of the most common management strategies for $U$. europaeus in rural areas of south-central Chile is controlled burn. However, exposure of the soil seedbank to fire can significantly increase seed germination of $U$. europaeus, producing intensive regeneration of new plants from the soil seedbank (Broadfield and McHenry, 2019).

Almost all plant species can interact with endophytic microorganisms as a way to improve fitness to several stressed environments (Fuentes et al., 2020; Lata et al., 2018). Endophytes are a group of bacterial and fungal strains that can live asymptomatically inside plant tissues without causing symptoms of disease (Eid et al., 2019; Herrera et al., 2019a). However, the specific benefits of several

endophytic microorganisms for the associated plants are mainly unknown (Bamisile et al., 2018; Ortiz et al., 2019). Recent studies have demonstrated that root endophytes can produce metabolites with antifungal properties to avoid pathogen infection of young seedlings (Terhonen et al., 2016), help wild plants to increase growth (Herrera et al., 2020b), improve tolerance to abiotic stress (Lata et al., 2018), reduce herbivory (Bamisile et al., 2018) or protect against oxidative burst (Khare et al., 2018). Therefore, due to its rigorous invasiveness, it is expected that specific interactions with soil microorganisms at early developmental stages can contribute to the rapid growth and development of this invasive shrub.

The aim of this study was to isolate root-associated microorganisms from $U$. europaeus plantlets colonizing native ecosystems in south-central Chile and to screen for their plant growth promoting capabilities. As far as we know, this is the first study of early growth stage endophytic interactions of the invasive shrub $U$. europaeus colonizing ecosystems in the southern hemisphere.

\section{Materials And Methods}

Early growth stage $U$. europaeus plantlets were sampled in agricultural rural areas in a segment of the Nahuelbuta Mountain Range, south-central Chile ( $\left.38^{\circ} 34^{\prime} \mathrm{S} 72^{\circ} 56^{\prime} \mathrm{W}\right)$. The plantlets $(\mathrm{n}=20 ; 3 \mathrm{~cm}$ tall) were found in 4 sampling points 2 months after a cleaning and burning treatment of an agricultural soil. The soil samples were collected at a depth of $20 \mathrm{~cm}$ for chemical analysis (Fuentes et al., 2020).

The aerial parts of the plantlets were removed and the roots were intensively washed under running tap water to remove the rhizosphere soil. Then, the roots were deposited in $50 \mathrm{ml}$ Falcon tubes and washed 
five times with deionized water in a laminar flow cabinet. The cleaned roots were subsequently deposited in sterile $50 \mathrm{ml}$ Falcon tubes and surface disinfected according to Herrera et al. (2019b), where the roots were immersed in $50 \mathrm{ml}$ of a disinfection solution ( $30 \mathrm{ml}$ of sterile distilled water, $10 \mathrm{ml}$ of sodium hypochlorite and $10 \mathrm{ml}$ of $100 \%$ alcohol) for $5 \mathrm{~min}$, followed by ten washes in sterile deionized water. An aliquot of the last wash was plated in potato dextrose agar (PDA) and Luria Bertani agar (LBA) to rule out the presence of rhizospheric microorganisms in root surface. Six surface-sterilized root segments were placed in Petri dishes containing PDA media supplemented with streptomycin $\left(100 \mathrm{mg} \mathrm{l}^{-1}\right)$, Murashige and Skoog basal medium, oatmeal agar ( $4 \mathrm{~g}$ of oats $\mathrm{I}^{-1}, 10 \mathrm{~g}$ of agar, $\mathrm{pH}$ 5.6) supplemented with benomyl $\left(4 \mathrm{mg} \mathrm{l}^{-1}\right)$ to reduce growth of ascomycetes (Bruzone et al., 2015), and LBA supplemented with cycloheximide $\left(100 \mathrm{mg} \mathrm{l}^{-1}\right)$. The Petri dishes were incubated in darkness at room temperature until no new fungal and bacterial colonies were detected. Individual bacterial and fungal strains were purified in LBA and PDA, respectively, and classified according their phenotypic characteristics (i.e., growth rate, color, texture, colony border). Purified colonies were stored in individual plates at $4^{\circ} \mathrm{C}$ and periodically subcultured.

Liquid cultures of the purified fungal and bacterial strains were performed in potato dextrose broth (PDB) and Luria Bertani broth (LBB) respectively to perform DNA extraction. For fungi, six fungal squares $(\sim 0.5$ $\mathrm{cm}$ ) were inoculated in $100 \mathrm{ml}$ Erlenmeyer flasks containing $40 \mathrm{ml}$ of PDB and incubated for 3 weeks in darkness at room temperature and in an orbital shaker at $150 \mathrm{rpm}$. An aliquot of $8 \mathrm{ml}$ of medium containing fungal mycelia was taken to store purified strains at $-80^{\circ} \mathrm{C}$ in glycerol. The rest of the media were filtered and the mycelia were used for DNA extraction using the E.Z.N.A.® HP Fungal DNA Kit (Omega Bio-tek, Norcross, GA, USA), according to the manufacturer's recommendations. For bacteria, the purified strains were cultured in $15 \mathrm{ml}$ sterile Falcon tubes containing $5 \mathrm{ml}$ of LBB and cultured in darkness at room temperature and in an orbital shaker at $150 \mathrm{rpm}$. An aliquot of $800 \mu \mathrm{l}$ was taken to store the purified strains at $-80^{\circ} \mathrm{C}$ in glycerol. DNA extraction was performed from $1 \mathrm{ml}$ of the liquid culture using the Wizard $\AA$ Genomic DNA Purification Kit (Promega, Madison, WI, USA), according to the manufacturer's recommendations. DNA integrity was checked in a $1 \%$ agarose gel, quantified using the Qubit fluorometer (Thermo Fisher Scientific, Waltham, MA, USA) and standardized to $20 \mathrm{ng}^{-1}$.

The molecular identification of fungal strains was performed based on the nucleotide sequence of the internal transcribed spacers of the 18S rRNA gene, amplified by PCR using the ITS1 and ITS4 primers (White et al., 1990) following the PCR conditions reported in Herrera et al. (2020b). Similarly, bacterial strains were identified based on the partial 16S rRNA gene sequence, amplified by PCR using the 27F and 1942R primers (Miller et al., 2013) according to the PCR conditions detailed in Herrera et al. (2020a). The PCR amplicons were checked in a $1.5 \%$ agarose gel, quantified in a Qubit fluorometer (Thermo Fisher Scientific) and sequenced at Macrogen (Seoul, South Korea). The nucleotide sequences were compared with those in the GenBank database of the National Center for Biotechnology using BLAST (https://blast.ncbi.nlm.nih.gov/Blast.cgi), accepting genus at an identity match greater than $95 \%$ and species at an identity greater than $99 \%$, as suggested by Chen et al. (2011). The sequences were aligned using the ClustalX software with default conditions for gap opening and gap extension penalty (Larkin et 
al., 2007) and non-conserved regions were removed using the BioEdit software v7.2 (Hall, 1999). Operative taxonomic units (OTUs) were assigned at $97 \%$ sequence similarity. The nucleotide sequences obtained were submitted to the GenBank database under the codes MW599973 to MW599982 for bacteria and MW604808 to MW604810 for fungi.

Screening of plant growth-promoting traits of the root-associated microorganisms was performed following standard procedures. The capacity to utilize tricalcium phosphate on agar, indole acetic acid (IAA) production and siderophore production were screened as reported in Soto et al. (2019). Briefly, microorganisms were assayed on Pikovskaya agar plates and incubated in darkness at $26 \pm 2{ }^{\circ} \mathrm{C}$ for 7 days. A clear halo around cultures indicated solubilization of tricalcium phosphate $\left(\mathrm{Ca}_{3}\left(\mathrm{PO}_{4}\right)_{2}\right)$. For IAA, microorganisms were cultured in LB or potato dextrose broth $1 / 7$ strength, supplemented with $0.5 \mathrm{mg} \mathrm{ml}$ - 1 of $\mathrm{L}$ - tryptophan and then incubated in darkness, under stirring at $150 \mathrm{rpm}$ and $26 \pm 2{ }^{\circ} \mathrm{C}$ for 5 days. After incubation, Salkowski's reagent was added to the cell suspension and measured at $530 \mathrm{~nm}$ in a BKUV1800 spectrophotometer (Biobase, Jinan, China). To determine siderophore production, the isolates were cultured in chrome azurol S (CAS) agar for 5 days, and CAS reaction was determined by color change in the blue CAS agar. Production of exopolysaccharides (EPS) was evaluated following Freeman et al. (1989), where isolates were streaked onto Congo red agar plates and incubated in darkness at $26 \pm$ $2^{\circ} \mathrm{C}$ for $48 \mathrm{hr}$. The EPS production was detected by variation in colony color. For ammonia production, microorganisms were grown in $4 \%$ peptone broth and incubated for 7 days in darkness under stirring at $28 \pm 2^{\circ} \mathrm{C}$. After incubation, Nessler's reagent was added to cell suspension and measured at $450 \mathrm{~nm}$ in a BK-UV1800 spectrophotometer (Biobase) (Bhattacharyya et al., 2020). The 1-aminocyclopropane-1carboxylic acid (ACC) deaminase activity was measured according to the free living bacteria method described by Brígido et al. (2015). Briefly, isolates were cultured in tryptic soy broth overnight in darkness, at $26 \pm 2^{\circ} \mathrm{C}$ and $150 \mathrm{rpm}$, and then collected by centrifugation. The cell pellet was washed twice with Dworkin and Foster (DF) salts minimal medium (without a $\mathrm{N}$ source) and re-suspended in DF salt minimal medium with $3 \mathrm{mM}$ ACC for $24 \mathrm{~h}$. Cultures were collected by centrifugation and the cell pellet was used for enzyme activity. The absorbance was measured at $540 \mathrm{~nm}$ in a BK-UV1800 spectrophotometer (Biobase). Finally, a biocontrol assay was performed to evaluate the potential of the isolates against phytopathogenic fungal species (Fusarium oxysporum, Botrytis cinerea, Rhizoctonia solani, Phoma herbarum) following Jamali et al. (2020). Briefly, a $5 \mathrm{~mm}$ diameter disk of a fresh culture of phytopathogenic fungi was placed in the center of a nutrient agar-potato dextrose agar (1:1) mix plate. Then, bacterial isolates were streaked on both sides of the fungal inoculum at a similar distance of 25 $\mathrm{mm}$ and incubated for 7 days at $28 \pm 2^{\circ} \mathrm{C}$ in darkness. For fungi, $5 \mathrm{~mm}$ diameter mycelia disks were placed at both sides of the phytopathogenic strains at a similar distance of $25 \mathrm{~mm}$ and incubated for 7 days at $28 \pm 2^{\circ} \mathrm{C}$ in darkness. The percentage of inhibition was calculated using the following formula:

\section{$\%$ Inhibition $=\left(\frac{\mathrm{C}-\mathrm{T}}{\mathrm{C}}\right) \times 100$}

where $\mathrm{C}$ is growth in $\mathrm{mm}$ in the control and $\mathrm{T}$ is growth in $\mathrm{mm}$ in the treatment with the isolates. 
The quantitative data were analyzed by one-way ANOVA, establishing significant differences at $p<0.05$. Post hoc pairwise comparisons were performed using Tukey's multiple range test. All statistical tests were conducted using the R software (R Core Team 2018; https://www.R-project.org).

\section{Results}

The soil chemical analysis showed that the sampling sites had similar content of nitrogen, phosphorous, potassium soil organic matter and $\mathrm{pH}$ ranging from 5.3 to 5.8 . High extractable aluminum levels were detected in the sampling points, with values ranging from 386 to $526 \mathrm{mg} \mathrm{kg}^{-1}$ (Table 1).

Table 1

Chemical characterization of soil colonized by Ulex europaeus in south-central Chile.

\begin{tabular}{|c|c|c|c|c|}
\hline & Sampling point 1 & Sampling point 2 & Sampling point 3 & Sampling point 4 \\
\hline $\mathrm{N}^{\mathrm{a}}$ & 9 & 11 & 12 & 11 \\
\hline $\mathrm{P}_{\text {Olsen }}{ }^{\mathrm{a}}$ & 2 & 2 & 2 & 2 \\
\hline $\mathrm{K}^{\mathrm{a}}$ & 356 & 375 & 325 & 442 \\
\hline Organic matter ${ }^{b}$ & 5 & 5 & 5 & 4 \\
\hline$K^{c}$ & 0.91 & 0.96 & 0.83 & 1.13 \\
\hline $\mathrm{Na}^{\mathrm{C}}$ & 0.12 & 0.10 & 0.07 & 0.10 \\
\hline $\mathrm{Ca}^{\mathrm{C}}$ & 8.85 & 5.44 & 5.39 & 5.95 \\
\hline $\mathrm{Mg}^{\mathrm{C}}$ & 7.05 & 5.70 & 4.90 & 5.25 \\
\hline $\mathrm{Al}^{\mathrm{c}}$ & 0.11 & 1.58 & 1.22 & 0.72 \\
\hline $\mathrm{CEC}^{\mathrm{C}}$ & 17.04 & 13.78 & 12.41 & 13.15 \\
\hline $\mathrm{pH}^{\mathrm{d}}$ & 5.8 & 5.3 & 5.4 & 5.5 \\
\hline $\mathrm{Al}_{\text {extractable }}{ }^{\mathrm{a}}$ & 386 & 510 & 526 & 455 \\
\hline \multicolumn{5}{|c|}{${ }^{\mathrm{a}} \mathrm{mg} \mathrm{kg}^{-1}$ (total contents) } \\
\hline \multicolumn{5}{|l|}{${ }^{\mathrm{c}} \mathrm{meq} / 100 \mathrm{~g}$} \\
\hline${ }^{d} \ln \mathrm{H}_{2} \mathrm{O}$ & & & & \\
\hline
\end{tabular}


A total of 79 bacterial colonies were isolated from the analyzed roots, which were separated into 12 different strains based on the morphological characteristic of the colonies and growth rate in culture media. The molecular identification of the isolates revealed 9 OTUs, with a dominance of the phyla Proteobacteria and Actinobacteria (Table 2). Specifically, the isolates UB7 (Novosphingobium sp.), UB9 (Herbaspirillum sp.), UB2 (Paraburkholderia strydomiana), UB4 (Pseudomonas sp.) and UB10 (Herbaspirillum rhizosphaerae) were assigned to taxa included in the phylum Proteobacteria (Table 2). Similarly, the isolates UB5 (Rhodococcus sp.), UB1 (Terrabacter aerolatus) and UB11 (Jatrophihabitans sp.) were assigned to taxa included in the phylum Actinobacteria (Table 2). The isolates UB3 (Flavobacterium sp.) and UB6 (Paenibacillus odorifer) were assigned to the phyla Bacteroidetes and Firmicutes, respectively (Table 2). Most of the bacterial sequences were assigned to different OTUs, excluding isolates UB9 and UB10 (Herbaspirillum spp.). Isolates UB8 and UB12 were classified as unidentified bacteria (with no significant match in the GenBank database) (Table 2). 
Table 2

Molecular identification of endophytic microorganisms isolated from young Ulex europaeus plantlets colonizing native ecosystems in south-central Chile

\begin{tabular}{|c|c|c|c|c|c|}
\hline Isolate & $\begin{array}{l}\text { Genbank } \\
\text { Accesion } \\
\text { number }\end{array}$ & $\begin{array}{l}\text { Close relative } \\
\text { (Accession number) }\end{array}$ & $\begin{array}{l}\% \\
\text { identity }\end{array}$ & Source & Reference \\
\hline \multicolumn{6}{|c|}{ BACTERIA } \\
\hline UB3 & MW599973 & $\begin{array}{l}\text { Flavobacterium sp. } \\
\text { (KF999716) }\end{array}$ & 99 & $\begin{array}{l}\text { Luffa cylindrica } \\
\text { fruit }\end{array}$ & GenBank \\
\hline UB6 & MW599974 & $\begin{array}{l}\text { Paenibacillus odorifer } \\
(\mathrm{MH} 157242)\end{array}$ & 99 & Glacier & $\begin{array}{l}\text { (Sherpa et } \\
\text { al., 2019) }\end{array}$ \\
\hline UB5 & MW599975 & $\begin{array}{l}\text { Rhodococcus sp. } \\
\text { (AB330417) }\end{array}$ & 100 & Soil & $\begin{array}{l}\text { (Miwa } \\
\text { and } \\
\text { Fujiwara, } \\
\text { 2009) }\end{array}$ \\
\hline UB1 & MW599976 & $\begin{array}{l}\text { Terrabacter aerolatus } \\
\text { (KF981511) }\end{array}$ & 98 & $\begin{array}{l}\text { Contaminated } \\
\text { soil }\end{array}$ & GenBank \\
\hline UB9 & MW599977 & $\begin{array}{l}\text { Herbaspirillum sp. } \\
\text { (LC372610) }\end{array}$ & 97 & $\begin{array}{l}\text { Ectomycorrhizal } \\
\text { root tips }\end{array}$ & $\begin{array}{l}\text { (Obase, } \\
\text { 2019) }\end{array}$ \\
\hline UB7 & MW599978 & $\begin{array}{l}\text { Novosphingobium sp. } \\
\text { (MN989139) }\end{array}$ & 95 & $\begin{array}{l}\text { Raxinus } \\
\text { excelsior } \\
\text { leaves }\end{array}$ & $\begin{array}{l}\text { (Ulrich et } \\
\text { al., 2020) }\end{array}$ \\
\hline UB11 & MW599981 & $\begin{array}{l}\text { Jatrophihabitans sp. } \\
\text { (MK875945) }\end{array}$ & 99 & Plant & GenBank \\
\hline UB2 & MW599979 & $\begin{array}{l}\text { Paraburkholderia } \\
\text { strydomiana } \\
\text { (NR164971) }\end{array}$ & 100 & Root nodules & $\begin{array}{l}\text { (Beukes et } \\
\text { al., 2019) }\end{array}$ \\
\hline UB4 & MW599980 & $\begin{array}{l}\text { Pseudomonas sp. } \\
\text { (MT012080) }\end{array}$ & 100 & Unknown & GenBank \\
\hline UB10 & MW599982 & $\begin{array}{l}\text { Herbaspirillum } \\
\text { rhizosphaerae } \\
\text { (MF509845) }\end{array}$ & 99 & $\begin{array}{l}\text { Polygonatum } \\
\text { cyrtonema } \\
\text { endosphere }\end{array}$ & GenBank \\
\hline UB8 & - & Unidentified & - & - & - \\
\hline UB12 & - & Unidentified & - & - & - \\
\hline
\end{tabular}




\begin{tabular}{|llllll|}
\hline Isolate & $\begin{array}{l}\text { Genbank } \\
\text { Accesion } \\
\text { number }\end{array}$ & $\begin{array}{l}\text { Close relative } \\
\text { (Accession number) }\end{array}$ & $\begin{array}{l}\text { \% } \\
\text { identity }\end{array}$ & Source & Reference \\
\hline UF1 & MW604808 & $\begin{array}{l}\text { Fusarium acuminatum } \\
\text { (MT514385) }\end{array}$ & 100 & Soil & GenBank \\
\hline UF2 & MW604809 & $\begin{array}{l}\text { Purpureocillium } \\
\text { lilacinum (MT530235) }\end{array}$ & 100 & Unknown & GenBank \\
\hline UF6 & MW604810 & $\begin{array}{l}\text { Acremonium alternatum } \\
\text { (MG807327) }\end{array}$ & 100 & $\begin{array}{l}\text { Mediterranean } \\
\text { Sea }\end{array}$ & GenBank \\
\hline UF5 & - & Unidentified & - & - & - \\
\hline
\end{tabular}

A total of 18 fungal strains were isolated, which were classified into 6 different isolates based on the morphological characteristics of the fungal strains. The molecular identification revealed 3 OTUs and showed Ascomycetes as the principal endophytic phylum associated with $U$. europaeus. Specifically, the isolates UF1 (Fusarium acuminatum), UF2 (Purpureocillium lilacinum) and UF6 (Acremonium alternatum) were related to taxa belonging to the phylum Sordariomycetes (Table 2). The isolate UF5 was classified as unidentified endophytic fungus (without significant match in the GenBank database) (Table 2). Isolates UF3 and UF4 did not grow in synthetic media after initial extraction and purification.

The screening of plant growth-promoting traits showed diverse capabilities associated with the different isolates (Table 3). Solubilization of $\mathrm{Ca}_{3}\left(\mathrm{PO}_{4}\right)_{2}$ in agar was detected only in $P$. strydomiana, whereas for fungi $P$. lilacinum and unidentified fungi (isolate UF5) showed $\mathrm{Ca}_{3}\left(\mathrm{PO}_{4}\right)_{2}$ solubilization capability (Table 3). Production of EPS was detected in P. lilacinum, P. odorifer, P. strydomiana and unidentified bacteria isolate UB8, whereas siderophore production was detected in $P$. strydomiana and $P$. lilacinum (Table 3). Almost all tested isolates showed ammonia production capability (14 out 16), being significantly high in the fungal isolate F. acuminatum (Fig. 1). The IAA production was similar for all bacterial isolates with higher values in Pseudomonas sp., whereas for the fungus $F$. acuminatum, it showed the highest production values detected in the study (Fig. 1). The ACC deaminase activity was significantly higher in the unidentified bacteria isolate UB8 (Fig. 1), whereas no ACC deaminase activity was detected for fungi. Biocontrol potential against potential phytopathogenic fungal strains was detected in 6 out of 16 isolates, with inhibition percentages ranging from $65.8 \pm 8.7$ (Rhodococcus sp.) to $11.1 \pm 1.9$ (A. alternatum) (Table 3). Specifically, the isolates Rhodococcus sp., unidentified bacteria (isolate UB8), F. acuminatum and P. lilacinum showed the highest inhibition percentages against the phytopathogenic fungi (Table 3). 
Table 3

Plant growth-promoting traits and biocontrol activity of endophytic microorganisms isolated from young Ulex europaeus plantlets. Values are expressed as means \pm standard deviation with $n=3$. - means no activity, + means positive activity, and + + means high production. Column values with the same letter are not significantly different according to Tukey's multiple range test $(p<0.05)$.

\begin{tabular}{|c|c|c|c|c|c|c|c|}
\hline \multirow[t]{2}{*}{ Isolate } & \multirow[t]{2}{*}{$\mathrm{P}^{\mathrm{a}}$} & \multirow[t]{2}{*}{ EPS $^{b}$} & \multirow[t]{2}{*}{$\operatorname{SID}^{c}$} & \multicolumn{4}{|c|}{ Biocontrold $^{d}$} \\
\hline & & & & $\begin{array}{l}\text { Botrytis } \\
\text { cinerea }\end{array}$ & $\begin{array}{l}\text { Rhizoctonia } \\
\text { solani }\end{array}$ & $\begin{array}{l}\text { Phoma } \\
\text { herbarum }\end{array}$ & $\begin{array}{l}\text { Fusarium } \\
\text { oxysporum }\end{array}$ \\
\hline \multicolumn{8}{|l|}{ Bacteria } \\
\hline Flavobacterium sp. UB3 & - & + & - & - & - & - & - \\
\hline $\begin{array}{l}\text { Paenibacillus odorifer } \\
\text { UB6 }\end{array}$ & - & + & - & - & - & - & - \\
\hline Rhodococcus sp. UB2 & - & - & - & $\begin{array}{l}65.8 \pm \\
8.7 \mathrm{c}\end{array}$ & $13.9 \pm 6.1 \mathrm{a}$ & $\begin{array}{l}48.9 \pm 1.8 \\
C\end{array}$ & $60.2 \pm 5.8 \mathrm{c}$ \\
\hline $\begin{array}{l}\text { Terrabacter aerolatus } \\
\text { UB1 }\end{array}$ & - & - & - & - & - & - & - \\
\hline Herbaspirillum sp. UB9 & - & - & - & - & - & - & - \\
\hline $\begin{array}{l}\text { Novosphingobium sp. } \\
\text { UB7 }\end{array}$ & - & - & - & - & - & - & - \\
\hline $\begin{array}{l}\text { Jatrophihabitans sp. } \\
\text { UB11 }\end{array}$ & - & - & - & - & - & - & - \\
\hline $\begin{array}{l}\text { Paraburkholderia } \\
\text { strydomiana UB2 }\end{array}$ & ++ & + & + & - & - & - & - \\
\hline Pseudomonas sp. UB4 & - & - & - & - & - & - & - \\
\hline $\begin{array}{l}\text { Herbaspirillum } \\
\text { rhizosphaerae UB10 }\end{array}$ & - & - & - & - & - & - & - \\
\hline $\begin{array}{l}\text { Unidentified bacteria } \\
\text { isolate UB8 }\end{array}$ & - & + & - & $\begin{array}{l}61.4 \pm \\
9.3 \mathrm{bc}\end{array}$ & $24.4 \pm 6.1 \mathrm{a}$ & $\begin{array}{l}53.7 \pm 5.7 \\
c\end{array}$ & $55.4 \pm 3.0 \mathrm{c}$ \\
\hline $\begin{array}{l}\text { Unidentified bacteria } \\
\text { isolate UB12 }\end{array}$ & - & - & - & - & - & - & - \\
\hline \multicolumn{8}{|l|}{ Fungi } \\
\hline $\begin{array}{l}\text { Fusarium acuminatum } \\
\text { UF1 }\end{array}$ & - & - & - & $\begin{array}{l}48.2 \pm \\
1.2 \mathrm{ab}\end{array}$ & $53.6 \pm 2.1 \mathrm{c}$ & $\begin{array}{l}51.2 \pm 2.8 \\
\mathrm{c}\end{array}$ & $58.2 \pm 1.5 \mathrm{c}$ \\
\hline $\begin{array}{l}\text { Purpureocillium } \\
\text { lilacinum UF2 }\end{array}$ & + & - & + & $\begin{array}{l}38.8 \pm \\
3.1 \mathrm{a}\end{array}$ & $\begin{array}{l}46.8 \pm 0.7 \\
\mathrm{bc}\end{array}$ & $\begin{array}{l}25.9 \pm 8.5 \\
a b\end{array}$ & $33.8 \pm 0.8 b$ \\
\hline $\begin{array}{l}\text { Acremonium } \\
\text { alternatum UF6 }\end{array}$ & - & - & - & $\begin{array}{l}33.3 \pm \\
3.8 \mathrm{a}\end{array}$ & $26.6 \pm 1.8 a$ & $\begin{array}{l}11.1 \pm 1.9 \\
\mathrm{a}\end{array}$ & $24.0 \pm 3.5 a$ \\
\hline
\end{tabular}




\begin{tabular}{|c|c|c|c|c|c|c|c|}
\hline \multirow[t]{2}{*}{ Isolate } & \multirow[t]{2}{*}{$\mathbf{P}^{\mathrm{a}}$} & \multirow[t]{2}{*}{ EPS $^{b}$} & \multirow[t]{2}{*}{$\operatorname{SID}^{c}$} & \multicolumn{4}{|c|}{ Biocontrold $^{d}$} \\
\hline & & & & $\begin{array}{l}\text { Botrytis } \\
\text { cinerea }\end{array}$ & $\begin{array}{l}\text { Rhizoctonia } \\
\text { solani }\end{array}$ & $\begin{array}{l}\text { Phoma } \\
\text { herbarum }\end{array}$ & $\begin{array}{l}\text { Fusarium } \\
\text { oxysporum }\end{array}$ \\
\hline $\begin{array}{l}\text { Unidentified fungal } \\
\text { isolate UF5 }\end{array}$ & + & - & - & $\begin{array}{l}45.5 \pm \\
1.4 \mathrm{ab}\end{array}$ & $41.7 \pm 1.2 b$ & $\begin{array}{l}29.0 \pm 3.9 \\
b\end{array}$ & $57.8 \pm 0.8 c$ \\
\hline \multicolumn{8}{|c|}{ a Phosphate solubilization } \\
\hline \multicolumn{8}{|c|}{ b Exopolysaccharide production } \\
\hline \multicolumn{8}{|c|}{ c Siderophore production } \\
\hline d Inhibition percenta & & & & & & & \\
\hline
\end{tabular}

\section{Discussion}

Our study characterized bacterial and fungal communities associated to the early growth stage of $U$. europaeus growing in rural areas in south-central Chile. Plant growth-promoting traits and biocontrol potential of the isolates were demonstrated, providing novel evidence about beneficial interactions with endophytic microorganisms.

Despite prescribing burning and brush clearing are commonly used for the control of $U$. europaeus, high germination rates from the soil seed bank and rapid plantlet growth after burn have been documented (Broadfield and McHenry, 2019; Madrigal et al., 2012). It is supposed that at this early growth stage endophytic microorganisms can play crucial roles in the establishment of $U$. europaeus, contributing to successful invasiveness in prone areas. Our study provides evidence about several beneficial endophytes living in symbiosis with $U$. europaeus plantlets, some of which may contribute with nutrient solubilization (e.g., P. strydomiana, P. lilacinum), production of plant growth-regulators (e.g., Pseudomonas sp., T. aerolatus), and biocontrol potential (e.g., F. acuminatum, Rhodococcus sp.). These results are in line with recent studies analyzing the beneficial effects of microbial endophytes on growth-promotion and development of native species and those of agricultural interest (Durán et al., 2014; González-Teuber et al., 2017). Therefore, endophytic plant growth-promoting microorganisms can also be essential components at first growth stages of $U$. europaeus.

Early growth stage microbial interactions can play key roles in the establishment of invasive species in the ecosystems, contributing to stress tolerance, plant nutrition and development of the associated plants (Links et al., 2014; Rezki et al., 2018). In our study, we characterized a set of beneficial endophytes associated with initial developmental stages of $U$. europaeus plantlets, but the source of those microbial strains is unclear. Several microbial strains can be stimulated from the soil by root exudates or can be a component of the seed-associated microbiome, both influencing the seedling survival, plant health and productivity (Nelson, 2018). Both, soil-borne and seed-associated microbes can be a potential source of the different taxa identified in our study, but further studies are necessary to define if $U$. europaeus can 
associate with soil microorganisms without specificity or if these microbes are mainly seed-associated endophytes. Despite the source of such beneficial microbial taxa, our results suggest that the presence of multiple microbial endophytes with different plant growth-promoting traits can be one of the mechanisms explaining the high growth rates and effective establishment of $U$. europaeus. In fact, Pitzschke (2018) reported that microbial endophytes contribute to a rapid seed germination and plantlet development of Chenopodium quinoa even under harsh environmental conditions, which is in line with our results revealing diverse beneficial endophytes colonizing early growth stage $U$. europaeus plantlets. Indeed, microbial endophytes have commonly been detected in association with invasive species, where a key role of such endophytic taxa has been suggested for plant growth promotion, stress tolerance and herbicide resistance of invasive species (Sorty et al., 2016; Suryanarayanan, 2019; Vila-Aiub et al., 2003). Recently, Currie et al. (2020) analyzed and described endophytic fungal interactions of the invasive weed Impatiens glandulifera, where the presence of endophytic taxa acts as a barrier that limits the effectivity of biological control strategies. Thus, knowledge about microorganisms inhabiting the endosphere of invasive plants can provide essential information to understand the mechanisms underlining the invasiveness of species such as $U$. europaeus.

Plants from the Fabaceae family usually establish symbiosis with arbuscular mycorrhizal fungi and Nfixing bacteria, which can confer nutritional and physiological benefits on mature plants. As our study was based on culture-dependent methods, we only identified the $\mathrm{N}$-fixing nodulating bacterial genus Paraburkholderia, which has been described as a beneficial taxon associated with Mimosa pudica plants (Paulitsch et al., 2020). Such symbiotic microbial taxa have commonly been described as beneficial microorganisms, but other endophytic strains can also contribute to a successful plant establishment, especially at the beginning of the $U$. europaeus life cycle. In this sense, we have provided evidence about beneficial attributes of Fusarium endophytic strains associated with $U$. europaeus in biological control of phytopathogenic fungi and plant-growth promotion. Such fungal genus has commonly been reported as a plant pathogen, but recently the beneficial roles of Fusarium spp. in plant growth and development have come to be better understood (Jiang et al., 2019). Similarly, our results showed a strong production of plant-growth regulators by the endophytic strains Herbaspirillum spp. and Pseudomonas sp., which is in line with the studies by Ramos et al. (2020) and Chu et al. (2019) on Oryza sativa and Arabidopsis thaliana, respectively. Additionally, other commonly accepted plant growth-promoter genera were also detected in our analyses, such as Paenibacillus (Bakaeva et al., 2017), Paraburkholderia (Zuñiga et al., 2017), Novosphingobium (Rangjaroen et al., 2017), Flavobacterium (Menon et al., 2020) and Purpureocillium (Baron et al., 2020). Therefore, a set of microbial endophytes with multiple plant-growth promoting traits can positively influence the life cycle and physiological responses of young $U$. europaeus plants.

Biocontrol activity is an indirect benefit for plants hosting microbial endophytes. Our results detected $F$. acuminatum, unidentified bacteria (strain UB8) and Rhodococcus sp. as the microbial strains with the highest growth inhibition percentages. In fact, Clark et al. (2018) tested the biocontrol potential of a $F$. acuminatum strain isolated from a medicinal plant against Mycobacterium tuberculosis, showing that essential metabolites producing by the fungus were directly involved in the antimicrobial activity. 
Similarly, our results agree with Hormazabal and Piontelli (2009), who showed that crude extracts from endophytic fungal strains (including the genus Acremonium) have biocontrol activity against phytopathogenic fungal strains. Similarly, Vidal et al. (2020) also isolated and characterized endophytic fungi associated with the native plant Acacia caven and tested against $B$. cinerea. Regarding bacteria, strong biocontrol potential was detected in the isolate Rhodococcus sp., which agrees with Munaganti et al. (2015), who had described the biocontrol activity of a Rhodococcus strain against Pseudogymnoascus destructans. Similarly, we identified the bacterial genus Pseudomonas, which has been described as a bacterium with the ability for biocontrol of fungi (Rojas-Solís et al., 2018). Such increasing evidence about the biocontrol potential of endophytic strains may represent an opportunity to study the mechanisms underlining the high resistance of invasive species to phytopathogens. Therefore, the biocontrol potential can be an indirect mechanism by which endophytic microbial strains contribute to the successful and rapid growth of $U$. europaeus plantlets.

Andisol soils, where $U$. europaeus was sampled, have high levels of available aluminum that interfere with the normal growth and development (Mora et al., 2017). However, such high levels of aluminum seem not to be a problem for $U$. europaeus plantlets. It is expected that effective tolerance mechanisms can support colonization of acidic Andisols. One of the tolerance mechanisms can be related with specific interactions with microbial strains which can confer metal tolerance to their associated plants (Ortiz et al., 2019). This is the case of Rhodococcus sp., which has been described as a microbial strain with high tolerance to metal(loid)s (Kumari et al., 2019; Vergani et al., 2019). Such metal tolerance conferred by endophytic strains can have a positive role in the tolerance of phytotoxic aluminum levels for $U$. europaeus plants inhabiting acidic Andisols.

Our study results provide evidence of novel endophytic interactions of $U$. europaeus with soil-borne microorganisms, from which their plant growth-promoting traits as well as their biocontrol potential can be an additional mechanism to explain the high growth rates and establishment of $U$. europaeus. However, it is unclear if the high diversity of endophytic interactions is induced by the ability of $U$. europaeus to select beneficial soil microorganisms from the bulk soil, or if the microbial strains are part of the seed-associated microbiome. Additionally, microbial strains with multiple beneficial traits can be considered potential bioinoculants for improving the plant growth or screening for novel biocontrol strategies of phytopathogenic fungi.

\section{Declarations}

\section{Funding}

This study was supported by the Fondo Nacional de Desarrollo Científico y Tecnológico of Chile [grant numbers 1211857 and 3200134].

\section{Declaration of Competing Interest}

The authors declare no conflict of interest. 


\section{References}

1. Bakaeva MD, Chetverikov SP, Korshunova TY, Loginov ON (2017) The new bacterial strain Paenibacillus sp. IB-1: A producer of exopolysaccharide and biologically active substances with phytohormonal and antifungal activities. Prikl Biokhim Mikrobiol 53:204-212

2. Bamisile BS, Dash CK, Akutse KS, Keppanan R, Wang L (2018) Fungal endophytes: beyond herbivore management. Front Microbiol 9:544. https://doi.org/10.3389/fmicb.2018.00544

3. Baron NC, de Souza Pollo A, Rigobelo EC (2020) Purpureocillium lilacinum and Metarhizium marquandii as plant growth-promoting fungi. PeerJ 8:e9005. https://doi.org/10.7717/peerj.9005

4. Beukes CW, Steenkamp ET, Van Zyl E, Avontuur J, Chan WY, Hassen Al, Palmer M, Mthombeni LS, Phalane FL, Sereme TK, Venter SN (2019) Paraburkholderia strydomiana sp. nov. and Paraburkholderia steynii sp. nov.: rhizobial symbionts of the fynbos legume Hypocalyptus sophoroides. Anton Leeuw Int J G 112:1369-1385. https://doi.org/10.1007/s10482-019-01269-5

5. Bhattacharyya C, Banerjee S, Acharya U, Mitra A, Mallick I, Haldar A, Haldar S, Ghosh A, Ghosh A (2020) Evaluation of plant growth promotion properties and induction of antioxidative defense mechanism by tea rhizobacteria of Darjeeling, India. Sci rep 10:1-19.

https://doi.org/10.1038/s41598-020-72439-z

6. Bowman G, Tarayre M, Atlan A (2008) How is the invasive gorse Ulex europaeus pollinated during winter? A lesson from its native range. Plant Ecol 197:197-206. https://doi.org/10.1007/s11258007-9370-1

7. Brígido C, Duan J, Glick BR (2015) Methods to study 1-aminocyclopropane-1-carboxylate (ACC) deaminase in plant growth-promoting bacteria. In: Cassán F, Okon Y, Creus C (eds) Handbook for Azospirillum. Springer, Cham. https://doi.org/10.1007/978-3-319-06542-7_16

8. Broadfield N, McHenry MT (2019) A world of gorse: persistence of Ulex europaeus in managed landscapes. Plants 8:523. https://doi.org/10.3390/plants8110523

9. Bruzone MC, Fontenla SB, Vohník M (2015) Is the prominent ericoid mycorrhizal fungus Rhizoscyphus ericae absent in the Southern Hemisphere's Ericaceae? A case study on the diversity of root mycobionts in Gaultheria spp. from northwest Patagonia, Argentina. Mycorrhiza 25: 25-40. https://doi.org/10.1007/s00572-014-0586-3

10. Chen J, Hu KX, Hou XQ, Guo SX (2011) Endophytic fungi assemblages from 10 Dendrobium medicinal plants (Orchidaceae). World J Microbiol Biotechnol 27:1009-1016. https://doi.org/10.1007/s11274-010-0544-y

11. Christina M, Limbada F, Atlan A (2020) Climatic niche shift of an invasive shrub (Ulex europaeus): a global scale comparison in native and introduced regions. J Plant Ecol 13:42-50.

https://doi.org/10.1093/jpe/rtz041

12. Chu TN, Tran BTH, Van Bui L, Hoang MTT (2019) Plant growth-promoting rhizobacterium Pseudomonas PS01 induces salt tolerance in Arabidopsis thaliana. BMC Res Notes 12:1-7. https://doi.org/10.1186/s13104-019-4046-1 
13. Clark TN, Carroll M, Ellsworth K, Guerrette R, Robichaud GA, Johnson JA, Gray CA (2018) Antibiotic mycotoxins from an endophytic Fusarium acuminatum isolated from the medicinal plant Geum macrophyllum. Nat Pro Commun. https://doi.org/10.1177/1934578X1801301017

14. Currie AF, Gange AC, Ab Razak N, Ellison CA, Maczey N, Wood SV (2020) Endophytic fungi in the invasive weed Impatiens glandulifera: a barrier to classical biological control? Weed Res 60:50-59. https://doi.org/10.1111/wre.12396

15. Durán P, Acuña JJ, Jorquera MA, Azcón R, Paredes C, Rengel Z, de la Luz Mora M (2014) Endophytic bacteria from selenium-supplemented wheat plants could be useful for plant-growth promotion, biofortification and Gaeumannomyces graminis biocontrol in wheat production. Biol Fertil Soils 50:983-990. https://doi.org/10.1007/s00374-014-0920-0

16. Eid AM, Salim SS, Hassan SED, Ismail MA, Fouda A (2019) Role of Endophytes in Plant Health and Abiotic Stress Management. In: Kumar V, Prasad R, Kumar M, Choudhary DK (eds) Microbiome in Plant Health and Disease: Challenges and Opportunities. Springer, Singapore, pp 119-144. https://doi.org/10.1007/978-981-13-8495-0_6

17. Freeman D, Falkiner F, Keane C (1989) New method for detecting slime production by coagulase negative staphylococci. J Clin Pathol 42:872-874. https://doi.org/10.1136/jcp.42.8.872

18. Fuentes A, Herrera H, Charles TC, Arriagada C (2020) Fungal and bacterial microbiome associated with the rhizosphere of native plants from the Atacama Desert. Microorganisms 8:209. https://doi.org/10.3390/microorganisms8020209

19. González-Teuber M, Vilo C, Bascuñán-Godoy L (2017) Molecular characterization of endophytic fungi associated with the roots of Chenopodium quinoa inhabiting the Atacama Desert, Chile. Genom Data 11:109-112. https://doi.org/10.1016/j.gdata.2016.11.085

20. Gränzig T, Fassnacht FE, Kleinschmit B, Förster M (2021) Mapping the fractional coverage of the invasive shrub Ulex europaeus with multi-temporal Sentinel-2 imagery utilizing UAV orthoimages and a new spatial optimization approach. Int J Appl Earth Obs Geoinf. https://doi.org/10.1016/j.jag.2020.102281

21. Hall TA (1999) BioEdit: a user-friendly biological sequence alignment editor and analysis program for Windows 95/98/NT. Nucleic Acids Symp Ser 41:95-98.

https://doi.org/10.14601/Phytopathol_Mediterr-14998u1.29

22. Hao Z, Xie W, Jiang X, Wu Z, Zhang X, Chen B (2019) Arbuscular mycorrhizal fungus improves Rhizobium-Glycyrrhiza seedling symbiosis under drought stress. Agronomy 9:572. https://doi.org/10.3390/agronomy9100572

23. Herrera H, García-Romera I, Meneses C, Pereira G, Arriagada C (2019a) Orchid mycorrhizal interactions on the Pacific side of the Andes from Chile. A Review J Soil Sci Plant Nutr 19:187-202. https://doi.org/10.1007./s42729-019-00026-x

24. Herrera H, Novotná A, Ortiz J, Soto J, Arriagada C (2020a) Isolation and identification of plant growth-promoting bacteria from rhizomes of Arachnitis uniflora, a fully mycoheterotrophic plant in southern Chile. Appl Soil Ecol 149:103512. https://doi.org/10.1016/j.apsoil.2020.103512 
25. Herrera H, Sanhueza T, Martiarena R, Valadares R, Fuentes A, Arriagada C (2020b) Mycorrhizal fungi isolated from native terrestrial orchids from region of La Araucanía, southern Chile. Microorganisms 8:1120. https://doi.org/10.3390/microorganisms8081120

26. Herrera H, Soto J, de Bashan LE, Sampedro I, Arriagada C (2019b) Root-associated fungal communities in two populations of the fully mycoheterotrophic plant Arachnitis uniflora Phil. (Corsiaceae) in southern Chile. Microorganisms 7:586.

https://doi.org/10.3390/microorganisms7120586

27. Hormazabal E, Piontelli E (2009) Endophytic fungi from Chilean native gymnosperms: antimicrobial activity against human and phytopathogenic fungi. World J Microbiol Biotechnol 25:813-819. https://doi.org/10.1007/s11274-008-9953-6

28. Hornoy B, Atlan A, Roussel V, Buckley Y, Tarayre M (2013) Two colonisation stages generate two different patterns of genetic diversity within native and invasive ranges of Ulex europaeus. Heredity 111:355-363. https://doi.org/10.1038/hdy.2013.53

29. Jamali $H$, Sharma A, Srivastava AK (2020) Biocontrol potential of Bacillus subtilis RH5 against sheath blight of rice caused by Rhizoctonia solani. J Basic Microbiol 60:268-280. https://doi.org/10.1002/jobm.201900347

30. Jiang J, Zhang K, Cheng S, Nie Q et al (2019) Fusarium oxysporum KB-3 from Bletilla striata: an orchid mycorrhizal fungus. Mycorrhiza 29:531-540. https://doi.org/10.1007/s00572-019-00904-3

31. Khare E, Mishra J, Arora NK (2018) Multifaceted interactions between endophytes and plant: developments and prospects. Front Microbiol 9:2732. https://doi.org/10.3389/fmicb.2018.02732

32. Kumari N, Rana A, Jagadevan S (2019) Arsenite biotransformation by Rhodococcus sp.: characterization, optimization using response surface methodology and mechanistic studies. Sci Total Environ 687:577-589. https://doi.org/10.1016/j.scitotenv.2019.06.077

33. Larkin MA, Blackshields G, Brown NP, Chenna R et al (2007) Clustal W and Clustal X version 2.0. Bioinformatics 23:2947-2948. https://doi.org/10.1093/bioinformatics/btm404

34. Lata R, Chowdhury S, Gond SK, White JF Jr (2018) Induction of abiotic stress tolerance in plants by endophytic microbes. Lett Appl Microbiol 66:268-276. https://doi.org/10.1111/lam.12855

35. Links MG, Demeke T, Gräfenhan T, Hill JE, Hemmingsen SM, Dumonceaux TJ (2014) Simultaneous profiling of seed-associated bacteria and fungi reveals antagonistic interactions between microorganisms within a shared epiphytic microbiome on Triticum and Brassica seeds. New Phytol 202: 542-553. https://doi.org/10.1111/nph.12693

36. Madrigal J, Marino E, Guijarro M, Hernando C, Díez C (2012) Evaluation of the flamabbility of gorse (Ulex europaeus L.) managed by prescribed burning. Ann For Sci 69:387-397. https://doi.org/10.1007/s13595-011-0165-0

37. Menon RR, Kumari S, Viver T, Rameshkumar N (2020) Flavobacterium pokkalii sp. nov., a novel plant growth promoting native rhizobacteria isolated from pokkali rice grown in coastal saline affected agricultural regions of southern India, Kerala. Microbiol Res 240:126533. https://doi.org/10.1016/j.micres.2020.126533 
38. Miller CS, Handley KM, Wrighton KC, Frischkorn KR, Thomas BC, Banfield JF (2013) Short-read assembly of full-length $16 \mathrm{~S}$ amplicons reveals bacterial diversity in subsurface sediments. PloS One 8:e56018. https://doi.org/10.1371/journal.pone.0056018

39. Miwa H, Fujiwara T (2009) Isolation and identification of boron-accumulating bacteria from contaminated soils and active sludge. Soil Sci Plant Nutr 55:643-646. https://doi.org/10.1111/j.1747-0765.2009.00402.x

40. Mora M, Demanet R, Acuña JJ, Viscardi S, Jorquera M, Rengel Z, Durán P (2017) Aluminum-tolerant bacteria improve the plant growth and phosphorus content in ryegrass grown in a volcanic soil amended with cattle dung manure. Appl Soil Ecol 115:19-26. https://doi.org/10.1016/j.apsoil.2017.03.013

41. Munaganti RK, Naragani K, Muvva V (2015) Antimicrobial profile of Rhodococcus erythropolis VLRK_05 isolated from Mango Orchards. Int J of Pharm Sci Res 6(4):1805. https://doi.org/10.13040/IJPSR.0975-8232.6 1805-12

42. Nelson EB (2018) The seed microbiome: origins, interactions, and impacts. Plant Soil 422:7-34. https://doi.org/10.1007/s11104-017-3289-7

43. Norambuena H, Escobar S, Rodríguez F (2001) Biological control of Ulex europaeus L.: Introduction to Chile of two populations of the moth Agonopterix ulicetella (Staiton) (Lepidoctera: Oecophoridae). Agri Tec. https://doi.org/10.4067/S0365-28072001000100009

44. Obase K (2019) Bacterial community on ectomycorrhizal roots of Laccaria laccata in a chestnut plantation. Mycoscience 60:40-44. https://doi.org/10.1016/j.myc.2018.08.002

45. Ortiz J, Soto J, Fuentes A, Herrera H, Meneses C, Arriagada C (2019) The endophytic fungus Chaetomium cupreum regulates expression of genes involved in the tolerance to metals and plant growth promotion in Eucalyptus globulus roots. Microorganisms 7:490. https://doi.org/10.3390/microorganisms7110490

46. Quiroz C, Pauchard A, Maticorena A, Cavieres L (2009) Manual de plantas invasoras del Centro-Sur de Chile. Concepción, Chile

47. Paulitsch F, Dall'Agnol RF, Delamuta JRM, Ribeiro RA, da Silva Batista JS, Hungria M (2020) Paraburkholderia atlantica sp. nov. and Paraburkholderia franconis sp. nov., two new nitrogen-fixing nodulating species isolated from Atlantic forest soils in Brazil. Arch Microbiol 202:1369-1380. https://doi.org/10.1007/s00203-020-01843-w

48. Pitzschke A (2018) Molecular dynamics in germinating, endophyte-colonized quinoa seeds. Plant soil 422:135-154. https://doi.org/10.1007/s11104-017-3184-2

49. R Core Team (2018) R: A language and environment for statistical computing. R foundation for statistical computing, Vienna. https://R-project.org

50. Rahayu Y, Pratiwi I (2020) Increasing plant tolerance grown on saline soil: the role of tripartite symbiosis. Ann Biol 36:346-353

51. Ramos AC, Melo J, de Souza SB, Bertolazi AA et al (2020) Inoculation with the endophytic bacterium Herbaspirillum seropedicae promotes growth, nutrient uptake and photosynthetic efficiency in rice. 
Planta 252:1-8. https://doi.org/10.1007/s00425-020-03496-x

52. Rangjaroen C, Sungthong R, Rerkasem B, Teaumroong N, Noisangiam R, Lumyong S (2017) Untapped endophytic colonization and plant growth-promoting potential of the genus Novosphingobium to optimize rice cultivation. Microbes Environ 32:84-87. https://doi.org/10.1264/jsme2.ME16112

53. Rezki S, Campion C, Simoneau P, Jacques MA, Shade A, Barret M (2018) Assembly of seedassociated microbial communities within and across successive plant generations. Plant soil 422:67-79. https://doi.org/10.1007/s11104-017-3451-2

54. Rojas-Solís D, Zetter-Salmón E, Contreras-Pérez M, del Carmen Rocha-Granados M, Macías-Rodríguez L, Santoyo G (2018) Pseudomonas stutzeri E25 and Stenotrophomonas maltophilia CR71 endophytes produce antifungal volatile organic compounds and exhibit additive plant growthpromoting effects. Biocatal Agric Biotechnol 13:46-52. https://doi.org/10.1016/j.bcab.2017.11.007

55. Sharma MP, Grover M, Chourasiya D, Bharti A, Agnihotri R, Maheshwari HS, Pareek A, Buyer JS, Sharma SK, Schütz L (2020) Deciphering the role of trehalose in tripartite symbiosis among rhizobia, arbuscular mycorrhizal fungi, and legumes for enhancing abiotic stress tolerance in crop plants. Front Microbiol 11:509919. https://doi.org/10.3389/fmicb.2020.509919

56. Sherpa MT, Najar IN, Das S, Thakur N (2019) Culture independent bacterial diversity of Changme Khang and Changme Khangpu glaciers of North Sikkim, India. Environmental Sustainability 2:241253. https://doi.org/10.1007/s42398-019-00067-z

57. Sorty AM, Meena KK, Choudhary K, Bitla UM, Minhas P, Krishnani K (2016) Effect of plant growth promoting bacteria associated with halophytic weed (Psoralea corylifolia $\mathrm{L}$ ) on germination and seedling growth of wheat under saline conditions. Appl Biochem Biotechnol 180:872-882. https://doi.org/10.1007/s12010-016-2139-z

58. Soto J, Ortiz J, Herrera H, Fuentes A, Almonacid L, Charles TC, Arriagada C (2019) Enhanced arsenic tolerance in Triticum aestivum inoculated with arsenic-resistant and plant growth promoter microorganisms from a heavy metal-polluted soil. Microorganisms 7:348. https://doi.org/10.3390/microorganisms7090348

59. Suryanarayanan T (2019) Endophytes and weed management: a commentary. Plant Physiol Rep 24:576-579. https://doi.org/10.1007/s40502-019-00488-2

60. Terhonen E, Sipari N, Asiegbu FO (2016) Inhibition of phytopathogens by fungal root endophytes of Norway spruce. Biol Control 99:53-63. https://doi.org/10.1016/j.biocontrol.2016.04.006

61. Toma MA, Carvalho TSd, Guimarães AA, Costa EMd S, JSd MFMdS (2017) Tripartite symbiosis of Sophora tomentosa, rhizobia and arbuscular mycorhizal fungi. Braz J Microbiol 48:680-688. https://doi.org/10.1016/j.bjm.2017.03.007

62. Ulrich K, Becker R, Behrendt U, Kube M, Ulrich A (2020) A comparative analysis of ash leaf-colonizing bacterial communities identifies putative antagonists of Hymenoscyphus fraxineus. Front Microbiol 11:966. https://doi.org/10.3389/fmicb.2020.00966 
63. Vergani L, Mapelli F, Suman J, Cajthaml T, Uhlik O, Borin S (2019) Novel PCB-degrading Rhodococcus strains able to promote plant growth for assisted rhizoremediation of historically polluted soils. PloS One 14:e0221253. https://doi.org/10.1371/journal.pone.0221253

64. Vidal A, Parada R, Mendoza L, Cotoras M (2020) Endophytic fungi isolated from plants growing in central Andean precordillera of Chile with antifungal activity against Botrytis cinerea. J Fungi 6:149. https://doi.org/10.3390/jof6030149

65. Vila-Aiub MM, Martinez-Ghersa MA, Ghersa CM (2003) Evolution of herbicide resistance in weeds: vertically transmitted fungal endophytes as genetic entities. Evol Ecol 17:441-456. https://doi.org/10.1023/B:EVEC.0000005580.19018.fb

66. White TJ, Bruns T, Lee S, Taylor J (1990) Amplification and direct sequencing of fungal ribosomal RNA genes for phylogenetics. In: Innis MA, Gelfand DH, Sninsky JJ, White TJ (eds) PCR protocols: a guide to methods and applications. Academic Press, New York, pp 315-322

67. Wilgan R (2021) Dual and tripartite symbiosis of invasive woody plants. In: Shribastava N, Manhajan S, Varma A (Eds)

68. Symbiotic Soil Microorganisms. Springer International Publishing, pp 87-97 https://doi.org/10.1007/978-3-030-51916-2_5

69. Zuñiga A, Donoso RA, Ruiz D, Ruz GA, González B (2017) Quorum-sensing systems in the plant growth-promoting bacterium Paraburkholderia phytofirmans PsJN exhibit cross-regulation and are involved in biofilm formation. Mol Plant Microbe Interact 30:557-565.

https://doi.org/10.1094/MPMI-01-17-008-R

\section{Figures}

a

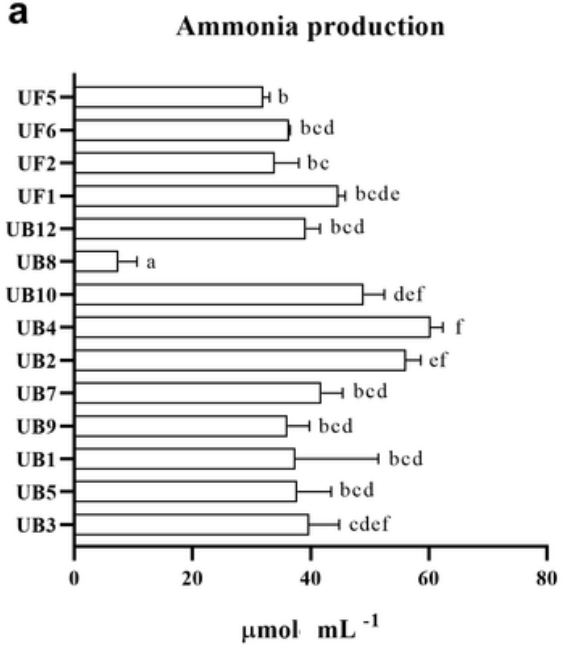

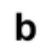

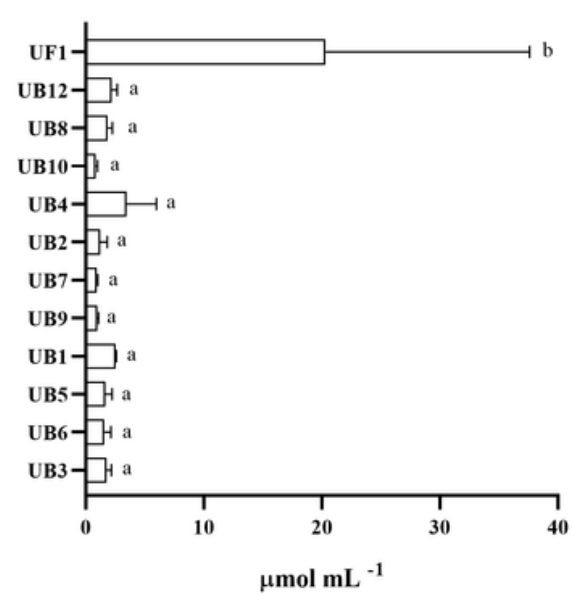

C ACC deaminase activity

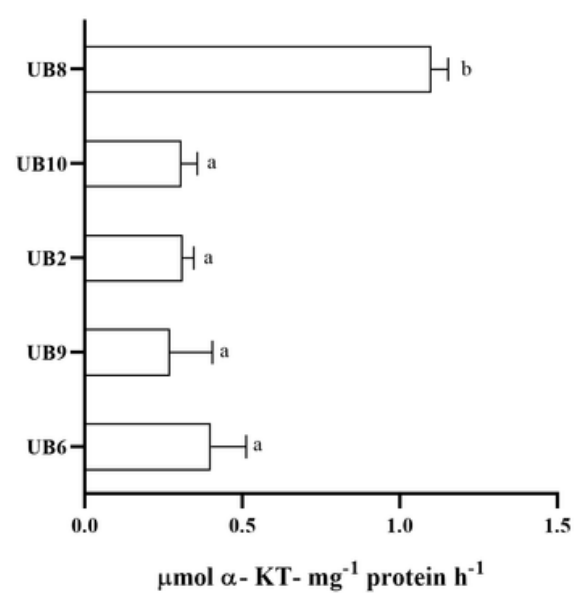

\section{Figure 1}

Ammonia production (a), indoleacetic acid (IAA) production (b) and 1-Aminocyclopropane-1-carboxylate (ACC) deaminase activity (c) of endophytic microorganisms isolated from young Ulex europaeus 
plantlets growing in south-central Chile. Values are expressed as means \pm standard deviation with $n=3$ and bars with the same letter are not significantly different according to Tukey's multiple range test ( $p$ $<0.05)$. 